\title{
IMAGEN 1-2013: ENFERMEDAD INFLAMATORIA DE LOS SENOS PARANASALES
}

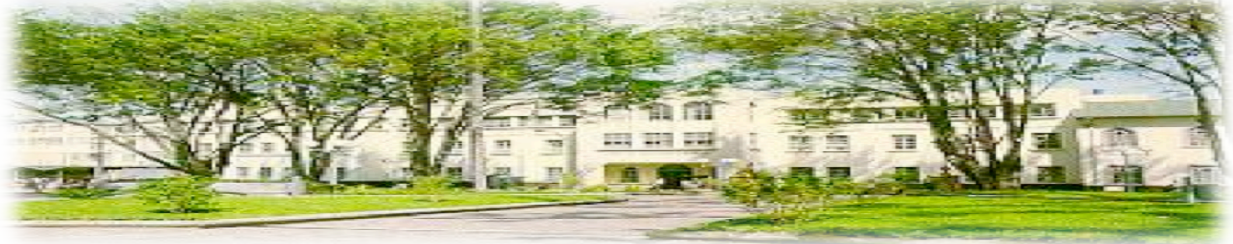

Haspital San quan de Dias. San José. Casta Riua. Fundada en 1845

\section{ISSN \\ 2215-2741}

Recibido:

Aceptado:
$01 / 02 / 2012$

$22 / 02 / 2012$
Carolina López-Vallejo Guzmán ${ }^{1}$ Manuel Caballero Barba ${ }^{2}$

${ }^{\mathbf{1}}$ Médico Residente en Radiología e Imágenes Médicas. SEP UCR-CENDEISSS. Hospital San Juan de Dios. Correo electrónico: lopezvallejoc@yahoo.com

${ }^{2}$ Médico Especialista en Radiología e Imágenes Médicas. Asistente del Servicio de Radiología. Hospital San Juan de Dios. Correo electónico: cabamanuel@gmail.com

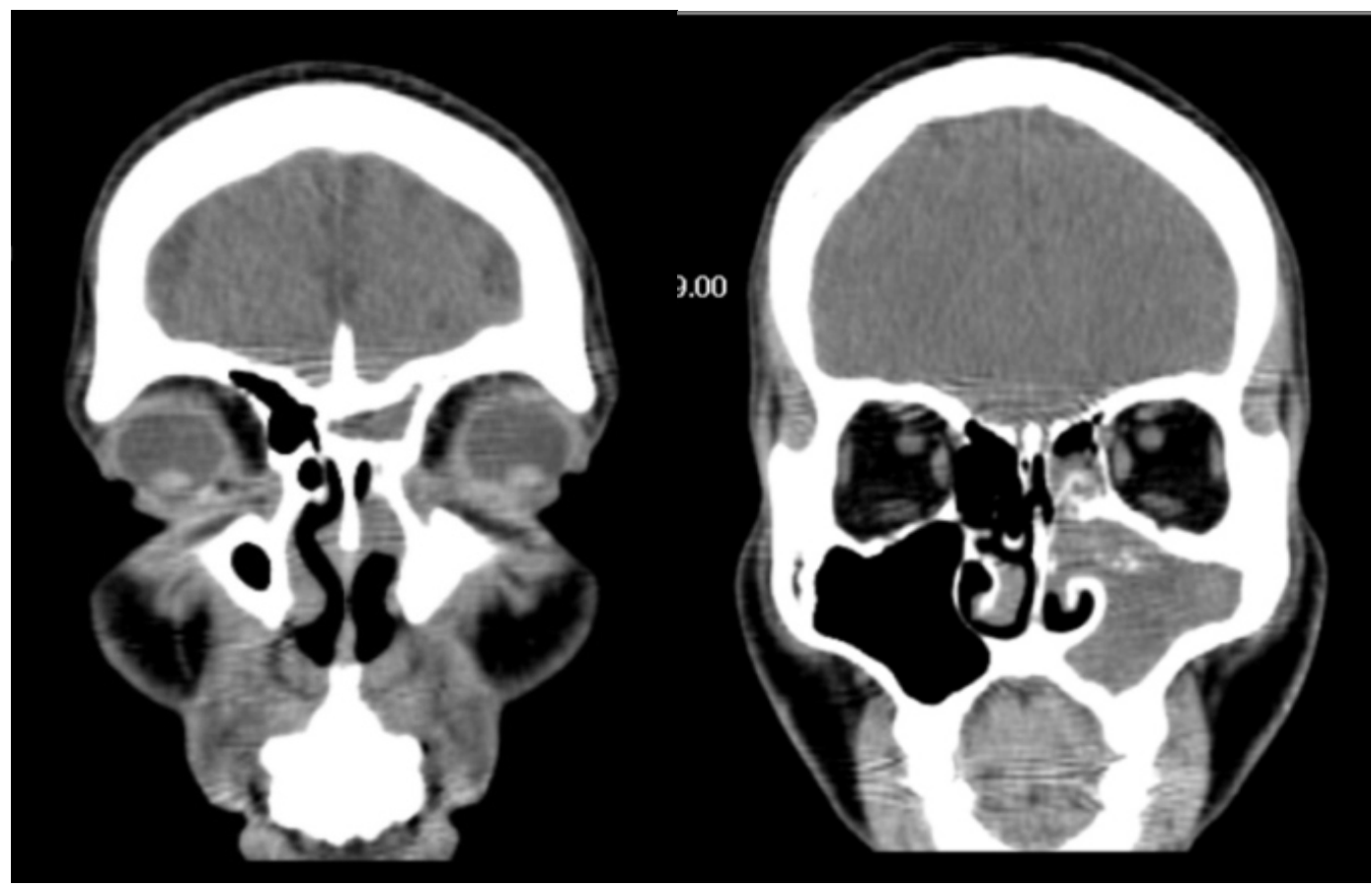




\section{CARACTERIZACIÓN DEL CASO}

Paciente masculino de 38 años, sin antecedentes médicos conocidos, quien acudió a la Consulta Externa de ORL del Hospital San Juan de Dios con cuadro de 6 meses de evolución de cefalea frontal, rinorrea purulenta y obstrucción nasal. En la rinoscopia se determinó rinorrea amarillenta en meato medio izquierdo, con el cornete medio aumentado de tamaño y desviación septal izquierda.

Figura 1. Tomografía de senos paranasales.

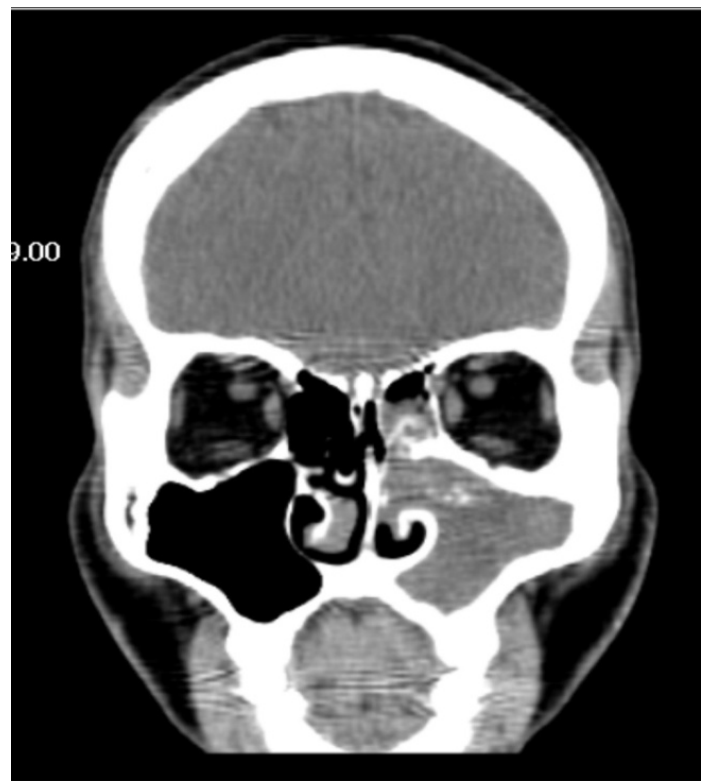

Descripción: tabique nasal ligeramente desviado a la izquierda. Antro maxilar izquierdo completamente ocupado por material de densidad tejidos blandos (33UH) con calcificaciones irregulares en su interior de hasta $4 \mathrm{~mm}$ que podrían corresponder con cronicidad. Dicha opacidad expande y oblitera el COM ipsilateral, erosiona la pared meatal del antro y del cornete medio. Hay importante engrosamiento y esclerosis de la pared ósea del seno maxilar izquierdo de predominio lateral. Se documente engrosamiento del cornete inferior. Fuente: Revisión del expediente clínico.

\section{DISCUSIÓN}

Sinusitis es el término empleado para describir la inflamación de los senos paranasales. Este proceso inflamatorio ocurre por infección, por inflamación y por variantes anatómicas. Las causas más frecuentes son procesos virales, bacterianos, fúngicos, alérgicos o por irritantes ambientales y afecta adultos en su mayoría jóvenes.

Figura 2. Tomografía de senos paranasales.

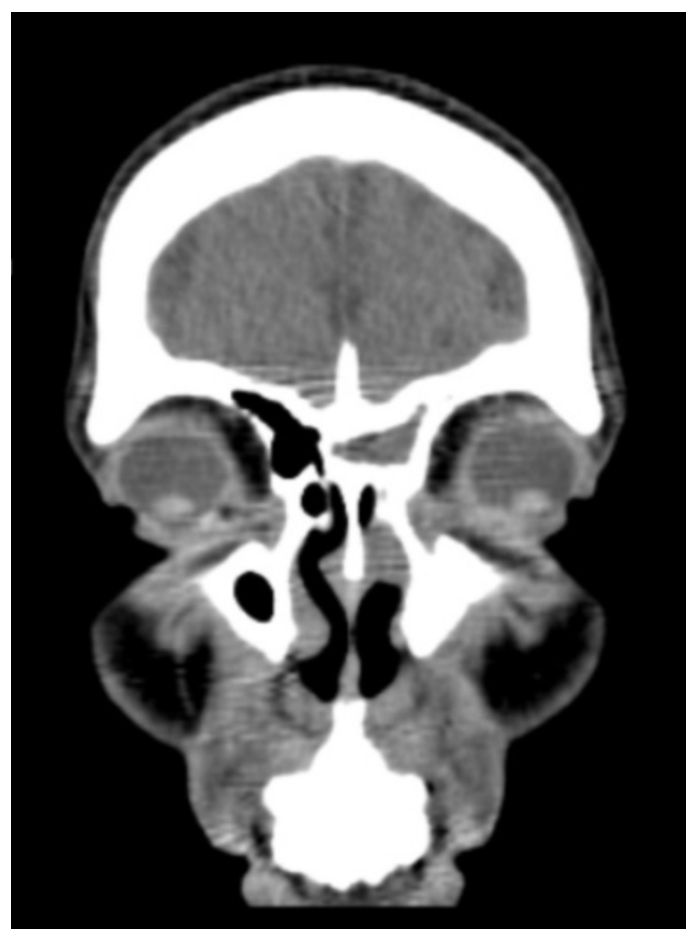

Descripción: material con densidad de tejidos blandos (33UH) que se origina en el seno maxilar izquierdo y continúa hasta el seno frontal izquierdo. Se documenta adecuada permeabilidad del complejo osteomeatal derecho.

Fuente: Revisión del expediente clínico.

La presentación clínica incluye malestar local, dolor en el seno afectado y rinorrea, en su mayoría de tipo purulenta. Usualmente se asocia a un proceso infeccioso de vías respiratorias subyacente.

Las bacterias patógenas más comunes son el Streptococcus pneumoniae y el Haemophilus influenzae y dentro de las causas virales más frecuentes están los rinovirus, virus influenza y parainfluenza.

La evaluación radiológica del proceso inflamatorio de los senos paranasales permite obtener una valoración anatómica, así como la extensión de la enfermedad. El análisis adecuado de los senos paranasales permite determinar el lugar de la obstrucción y así, puede explicar la 
causa y se convierte en una guía para la realización de un procedimiento quirúrgico posterior.

La apariencia radiológica de la patología de los senos paranasales puede clasificarse en aguda, ya sea de tipo viral o bacteriano y crónica, que a su vez puede ser de etiología fúngica (micetoma) o debida a poliposis nasal.

El signo radiológico más temprano de la enfermedad inflamatoria de los senos paranasales es el engrosamiento de la mucosa y puede ser el único hallazgo en el proceso agudo. Lo anterior puede alterar la aeración de los senos paranasales, por presencia de masa de tejido blando o la cavidad llena de secreciones retenidas y observarse un nivel hidroaéreo. Este hallazgo es importante porque permite establecer si el proceso es de carácter agudo.

Pueden originarse masas de tejidos blandos en los senos paranasales y los más frecuentes son los quistes de retención y los pólipos. Los cambios de las paredes óseas pueden mostrar desmineralización, adelgazamiento y expansión, esclerosis y destrucción ósea, hallazgos que pueden ser observados en los senos maxilares y frontales.

El hallazgo de desmineralización y pérdida de la línea mucosoperióstica sugiere que la infección está activa, mientras que cuando existe esclerosis de las paredes óseas se atribuye a inflamación de meses o años. El engrosamiento mucoso puede evaluarse por medio de la tomografía con medio de contraste: si la mucosa está engrosada no realza y lo más probable es que no exista infección activa sino fibrosis. Si el proceso inflamatorio es agudo existe realce de la mucosa asociado con edema.

Las complicaciones del proceso inflamatorio de los senos paranasales incluyen los quistes de retención mucosa; más frecuentes en el piso de los senos maxilares y ocurren en un $10 \%$ de la población, como resultado de la obstrucción de la glándula mucinosa. El mucocele corresponde a una lesión expansiva de los senos paranasales, que es secundaria a la obstrucción de un orificio sinusal, provocando presión intraluminal que expande la cavidad sinusal y erosiona las paredes óseas.
Los pólipos inflamatorios se producen como consecuencia de hiperplasia de la mucosa, en la mayoría de las ocasiones relacionados con cambios alérgicos del revestimiento mucoso, más frecuentemente a nivel de los senos maxilares. Se consideran las lesiones expansivas más frecuentes de la cavidad nasal.

\section{BIBLIOGRAFÍA}

1. Pedrosa C. Diagnóstico por Imagen Neurorradiologia. Editorial Marban 2009;459472.

2. Cornelius R. Sinonasal Disease. American College of Radiology ACR Appropriateness Criteria 2009;1-7.

3. Lee S. Cranial MRI and CT. Editorial McGraw-Hill 1994;823-840. 